\title{
BIOLOGY OF BRAIN DYSFUNCTION
}

\author{
Volume 2
}


A Continuation Order Plan is available for this series. A continuation order will bring delivery of each new volume immediately upon publication. Volumes are billed only upon actual shipment. For further information please contact the publisher. 


\section{BIOLOGY OF BRAIN DYSFUNCTION Volume 2}

\section{Edited by Gerald E. Gaull}

New York State Institute for Basic Research in Mental Retardation Staten Island, New York

and

Mount Sinai School of Medicine of the City University of New York New York, New York 
Library of Congress Catalog Card Number 72-80796

ISBN-13: 978-1-4684-2672-4

e-ISBN-13: 978-1-4684-2670-0

DOI: $10.1007 / 978-1-4684-2670-0$

() 1973 Plenum Press, New York

Softcover reprint of the hardcover 1st edition 1973

A Division of Plenum Publishing Corporation

227 West 17th Street, New York, N.Y. 10011

United Kingdom edition published by Plenum Press, London

A Division of Plenum Publishing Company, Ltd.

Davis House (4th Floor), 8 Scrubs Lane, Harlesden, London, NW10 6SE, England

\section{All rights reserved}

No part of this publication may be reproduced in any form without written permission from the publisher 


\section{CONTRIBUTORS TO THIS VOLUME}

\section{Andre Barbeau}

Department of Neurobiology, Clinical Research Institute of Montreal, Montreal, Quebec, Canada

John P. Blass

Departments of Biological Chemistry and Psychiatry and the Mental Retardation Center, Los Angeles, California

\section{Doris H. Clouet}

New York State Narcotic Addiction Control Commission, Testing and Research Laboratories, Brooklyn, New York

Marilyn Louise Cowger

Albany Medical College of Union University and State University of New York at Albany, New York

\section{Norbert N. Herschkowitz}

Department of Pediatrics, University of Berne, Berne, Switzerland

\section{Charles Kennedy}

Georgetown University Hospital, Washington, D.C.

\section{Marian W. Kies}

Section on Myelin Chemistry, Laboratory of Cerebral Metabolism, National Institute of Mental Health, Bethesda, Maryland

\section{Dorothy T. Krieger}

Neuroendocrinology Laboratory, Division of Endocrinology, Department of Medicine, Mount Sinai School of Medicine of the City University of New York, New York, New York

\section{Louis Sokoloff}

National Institute of Mental Health, Bethesda, Maryland 


\section{Daniel Steinberg}

Division of Metabolic Diseases, Department of Medicine, University of California, San Diego, La Jolla, California

\section{Kinuko Suzuki}

The Saul R. Korey Department of Neurology and Department of Pathology, Rose F. Kennedy Center for Research in Mental Retardation and Human Development, Albert Einstein College of Medicine, Bronx, New York

\section{Kunihiko Suzuki}

The Saul R. Korey Department of Neurology and Department of Pathology, Rose F. Kennedy Center for Research in Mental Retardation and Human Development, Albert Einstein College of Medicine, Bronx, New York

\section{A. G. Waltz}

Department of Neurology, University of Minnesota Medical School, Minneapolis, Minnesota 


\section{PREFACE}

The growth of neurochemistry, molecular biology, and biochemical genetics has led to a burgeoning of new information relevant to the pathogenesis of brain dysfunction. This explosion of exciting new information is crying out for collation and meaningful synthesis. In its totality, it defies systematic summation, and, of course, no one author can cope. Thus invitations for contributions were given to various experts in areas which are under active investigation, of current neurological interest, and pregnant. Although this project is relatively comprehensive, by dint of size, other topics might have been included; the selection was solely my responsibility.

I believe systematic summation a virtual impossibility-indeed, hardly worth the effort. The attempt to assemble all of the sections involved in a large treatise with multiple authors inevitably results in untoward delays due to the difference in the rate at which various authors work. Therefore, the following strategy has been adopted: multiple small volumes and a relatively flexible format, with publication in order of receipt and as soon as enough chapters are assembled to make publication practical and economical. In this way, the time lag between the ideas and their emergence in print is the shortest.

This book is aimed at research workers, students, and physicians interested in the pathogenesis of brain dysfunction. Clinical data have been included only when relevant to such an understanding, but the reader is provided with suitable source material for fuller clinical description and discussion. The emphasis in this book is on biological aspects of brain dysfunction. Although much current work is biochemical, there has been a conscious attempt to integrate structural, physiological, nutritional, and immunological approaches.

Gerald E. Gaull, M.D. 


\section{CONTENTS}

Chapter 1

Disorders of Sphingolipid Metabolism

Kunihiko Suzuki and Kinuko Suzuki

I. Introduction $\ldots \ldots \ldots \ldots \ldots \ldots \ldots \ldots \ldots \ldots \ldots \ldots \ldots \ldots \ldots \ldots$

II. Chemistry, Metabolism, and Distribution of Sphingolipids . . . . 2

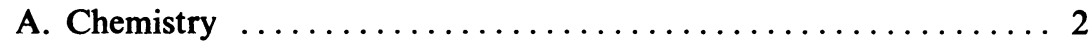

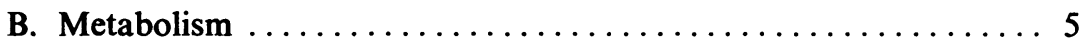

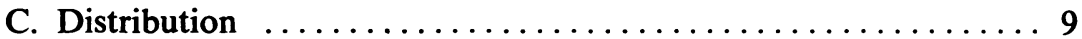

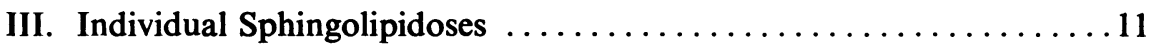

A. Sphingomyelinosis (Niemann-Pick Disease) $\ldots \ldots \ldots \ldots \ldots 12$

B. Glucosylceramide Lipidosis (Gaucher's Disease) $\ldots \ldots \ldots \ldots \ldots$

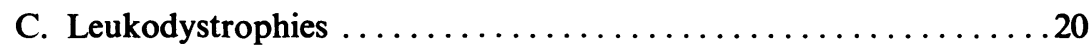

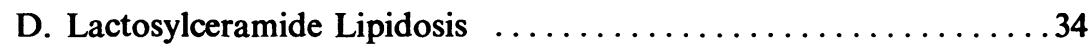

E. Trihexosylceramide Lipidosis (Fabry's Disease) $\ldots \ldots \ldots \ldots \ldots 35$

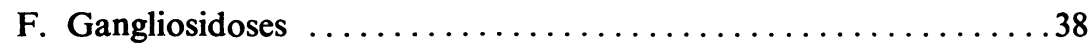

G. Miscellaneous Disorders $\ldots \ldots \ldots \ldots \ldots \ldots \ldots \ldots \ldots \ldots \ldots$

IV. Summary and Concluding Remarks $\ldots \ldots \ldots \ldots \ldots \ldots$

References .................................. 59

Chapter 2

Disorders of the Cerebral Circulation

A. G. Waltz

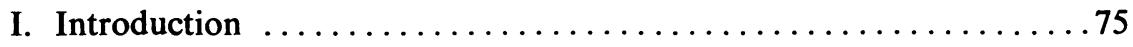

II. Methods for Study of the Cerebral Circulation $\ldots \ldots \ldots \ldots \ldots \ldots$

A. Cerebral Blood Flow and Cerebral Vascular Resistance ..... . 76

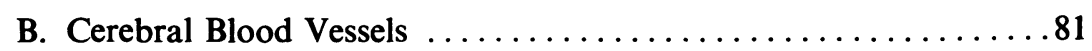


III. Regulation of the Cerebral Circulation $\ldots \ldots \ldots \ldots \ldots \ldots \ldots 83$

A. Regulatory Responses of Vascular Caliber and Blood Flow ... 83

B. Vascular, Neural, and Humoral Mechanisms for the Regulation of the Cerebral Circulation .............. 88

IV. Dysfunction of Regulatory Mechanisms $\ldots \ldots \ldots \ldots \ldots \ldots \ldots$. 91

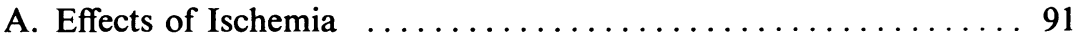

B. Effects of Hypoxemia and Hyperoxemia .............. 94

C. Effects of Increased Intracranial Pressure $\ldots \ldots \ldots \ldots \ldots \ldots . . \ldots 4$

D. Effects of Sustained Hypertension $\ldots \ldots \ldots \ldots \ldots \ldots \ldots . \ldots 9$

E. Effects of Miscellaneous Factors ................... 95

V. Intravascular Phenomena $\ldots \ldots \ldots \ldots \ldots \ldots \ldots \ldots \ldots \ldots \ldots$

A. Normal Cerebral Circulation ..................... 96

B. Abnormal Circulatory States .................... 97

VI. Secondary Effects of Disturbed Regulation ................. 100

A. Hyperemia and Venous Hyperoxemia $\ldots \ldots \ldots \ldots \ldots \ldots \ldots$

B. Cerebral Edema ............................... 102

C. "Diaschisis" and Generalized Decreases of CBF ........... 102

D. Cardiac and Systemic Effects....................... 103

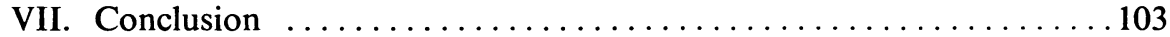

References ..................................... 104

Chapter 3

Effects of Narcotic Analgesics on Brain Function

Doris H. Clouet

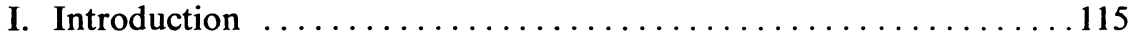

II. Physiological Effects of Narcotic Analgesics................. 117

A. Pharmacology of Narcotics . . . . . . . . . . . . . . . . 117

B. Alterations of Lower Brain Stem Functions by Narcotics . . . . 119

C. Alterations of Subcortical Functions by Narcotics ...........119

D. Alterations of Cortical Functions by Narcotics........... 120

III. Metabolism of Narcotic Analgesics in the Nervous System . . . . . . 121

A. Penetration and Distribution in the Nervous System ........121

B. Blood-Brain Barrier to Narcotics ...................... 122

C. Biotransformations of Narcotics ..................... 124

IV. Biochemical Responses to Narcotics . . . . . . . . . . . . . . 126

A. General Effects ............................... 126

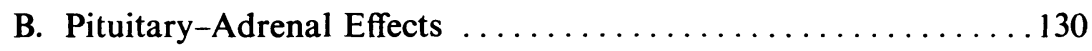


C. Role of the Biogenic Amines and Acetylcholine $\ldots \ldots \ldots \ldots 131$

D. Localization of Drug Responses ................. 134

E. Tolerance to Biochemical Responses $\ldots \ldots \ldots \ldots \ldots \ldots \ldots \ldots \ldots$

V. Electroencephalography ......................... 138

A. Electroencephalography in Experimental Animals.........138

B. Electroencephalography in Man................. 138

VI. Theories on the Mechanism of Addiction to Narcotics . . . . . . 139

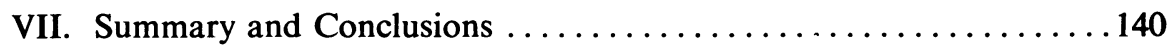

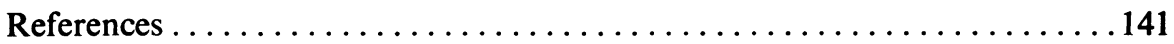

\section{Chapter 4}

Genetic Disorders of Brain Development: Animal Models

Norbert N. Herschkowitz

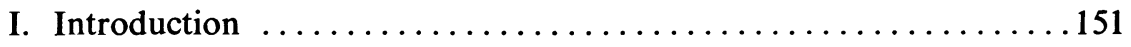

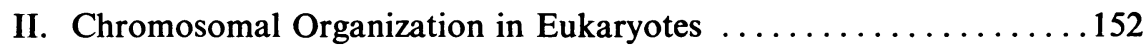

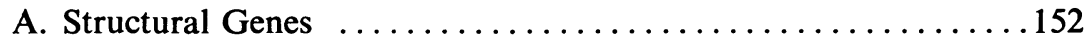

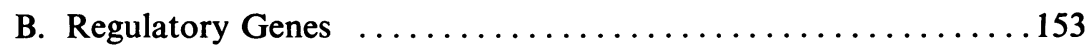

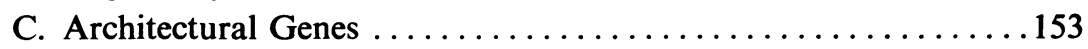

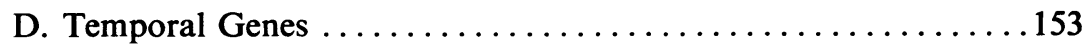

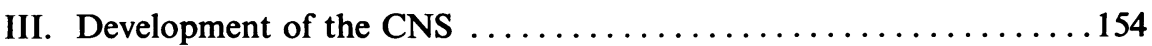

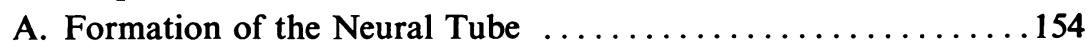

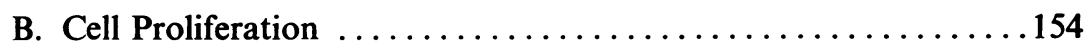

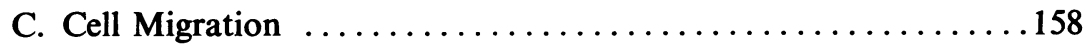

D. Differentiation of Neurons $\ldots \ldots \ldots \ldots \ldots \ldots \ldots \ldots \ldots \ldots \ldots$

E. Differentiation of Oligodendrocytes: Myelination $\ldots \ldots \ldots \ldots 160$

IV. Genetic Disorders of Brain Development ............... 162

A. Abnormal Induction of the Neural Tube $\ldots \ldots \ldots \ldots \ldots \ldots$

B. Abnormal Formation of the Neural Crest $\ldots \ldots \ldots \ldots \ldots 164$

C. Abnormal Folding of the Neural Tube ............... 164

D. Abnormal Induction of Sensory Organs $\ldots \ldots \ldots \ldots \ldots \ldots$

E. Abnormal Migration and Alignment of Cortical Cells . . . . . 167

F. Disorders of Myelin Formation ................... 169

G. Metabolic Disorders Which May Act on Different Levels

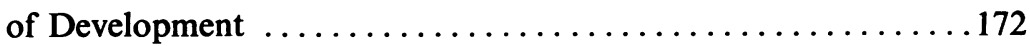

H. Increased Death Rate of Cells . . . . . . . . . . . . . . 174

I. Genetic Mutations Affecting Brain Metabolism .......... 175

V. Prevention of Brain Dysfunction $\ldots \ldots \ldots \ldots \ldots \ldots \ldots \ldots \ldots \ldots \ldots \ldots \ldots$

References ....................................... 
Chapter 5

Experimental Allergic Encephalomyelitis

Marian W. Kies

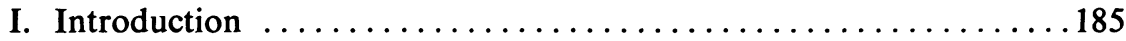

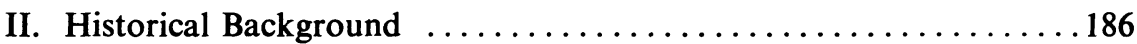

A. Clinical "Accidents" Related to Injections of CNS Tissue . . . 186

B. Induction of EAE in Laboratory Animals $\ldots \ldots \ldots \ldots \ldots \ldots$

III. Identification of Specific Encephalitogenic Components

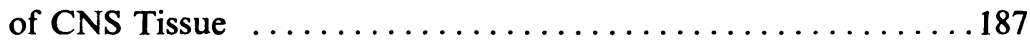

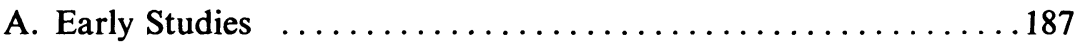

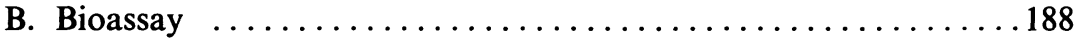

C. Isolation of the Encephalitogen and Its Characterization

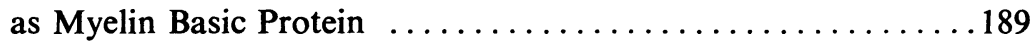

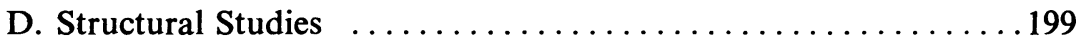

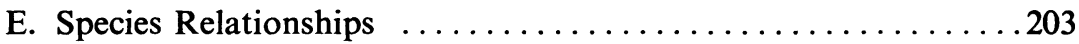

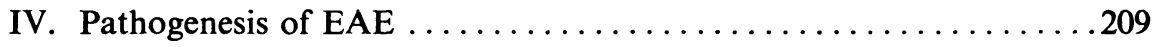

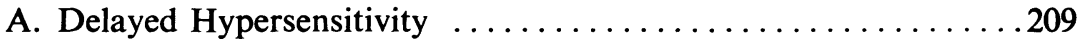

B. Role of Serum Antibody $\ldots \ldots \ldots \ldots \ldots \ldots \ldots \ldots \ldots \ldots \ldots 212$

V. Possible Relationship of EAE to Human Demyelinative

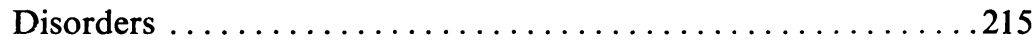

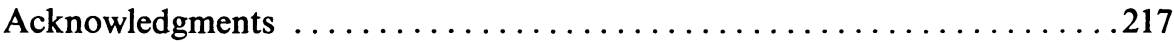

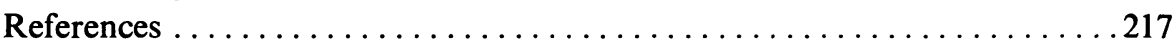

Chapter 6

Disorders of Fatty Acids

John P. Blass and Daniel Steinberg

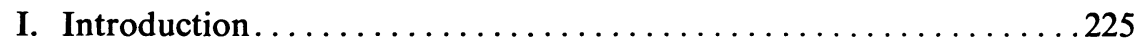

II. Fatty Acids in Normal Brain and Nerve ............... 226

A. Distribution and Composition of Fatty Acids in Brain

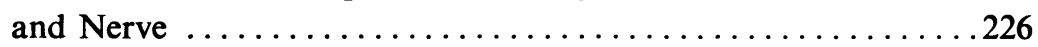

B. Origin of Brain Fatty Acids . . . . . . . . . . . . . 229

III. Phytanic Acid Storage Disease (Refsum's Disease) $\ldots \ldots \ldots \ldots 232$

A. Clinical and Biochemical Abnormalities .............. 232

B. Pathophysiology of Phytanic Acid Storage Disease . . . . . . . 235

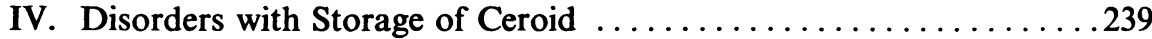

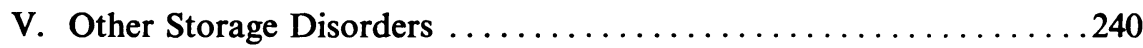

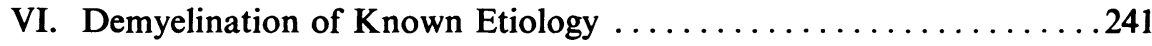

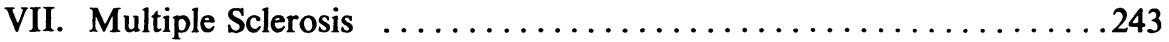

A. Abnormalities in Fatty Acids in Multiple Sclerosis . . . . . . 243

B. Relation of the Analytical Findings to the Clinical Syndrome 


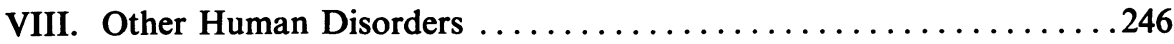

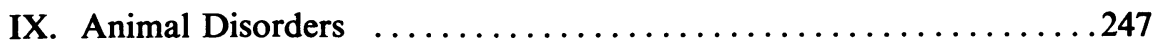

X. Criteria for Establishing Primary Disorders of Cerebral

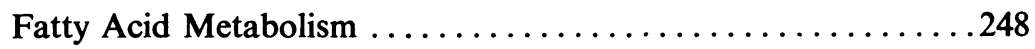

References ....................................... 249

Chapter 7

Bilirubin Encephalopathy

Marilyn Louise Cowger

I. Introduction and Historical Perspective $\ldots \ldots \ldots \ldots \ldots \ldots \ldots \ldots$

II. Chemistry and Metabolism of Bilirubin with Special Note of Variations Seen in the Newborn Period .............. 267

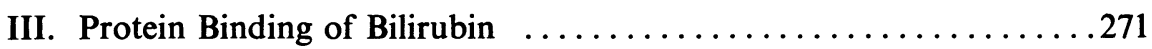

A. Influence of Molar Ratios and $p \mathrm{H}$ on Binding of

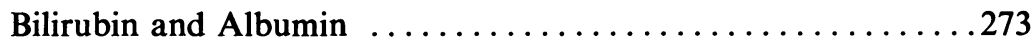

B. Other Factors Which Affect Binding of Bilirubin by Albumin ................................273

IV. Problems Hampering Research .................... 275

V. Pathological Lesion of Bilirubin Encephalopathy $\ldots \ldots \ldots \ldots \ldots 275$

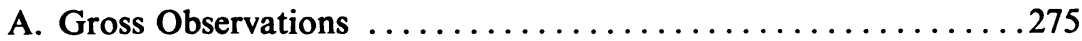

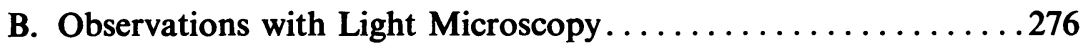

C. Observations with Electron Microscopy $\ldots \ldots \ldots \ldots \ldots \ldots 277$

VI. Extraneural Pathological Lesions Induced by Bilirubin . . . . . . . 277

VII. Metabolic Lesions Induced by Bilirubin $\ldots \ldots \ldots \ldots \ldots \ldots \ldots 278$

A. Effects of Bilirubin on Tissue Respiration ............ 278

B. Effects of Bilirubin on Lipids $\ldots \ldots \ldots \ldots \ldots \ldots \ldots \ldots \ldots \ldots 282$

C. Effects of Bilirubin on Cell Membrane Systems ............283

D. Other Metabolic Reactions .......................285

VIII. Why Is Brain Damage the Main Pathological Phenomenon Induced by Bilirubin? .......................286

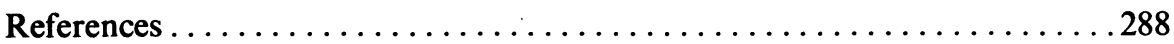

Chapter 8

The Action of Thyroid Hormones and Their Influence on Brain

Development and Function

Louis Sokoloff and Charles Kennedy

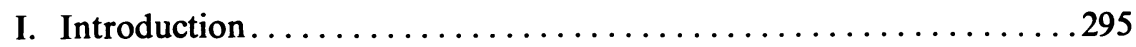

A. Chemical Nature of Thyroid Hormones ............. 296

B. General Biological and Biochemical Effects of Thyroid 
II. General Role of Thyroid Hormones in the Structural and Functional Maturation of the Nervous System . . . . . . . . . 309

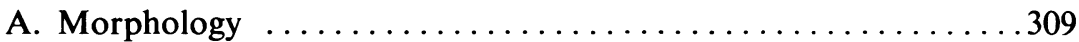

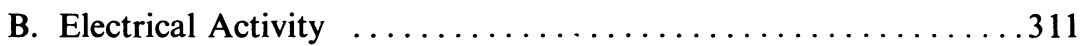

C. Behavior and Learning in Experimental Animals ..........311

D. Maturation of Brain Function in Man $\ldots \ldots \ldots \ldots \ldots \ldots \ldots \ldots \ldots \ldots$

E. Conclusions Regarding the Role of Thyroid Hormones in the Functional Development of the Nervous System .......317

III. Biochemical and Metabolic Effects of Thyroid Hormones

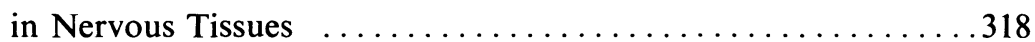

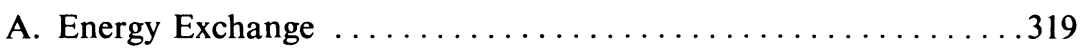

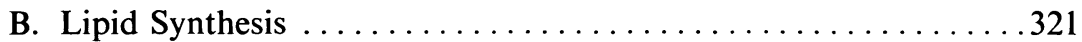

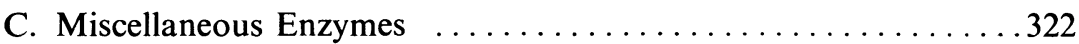

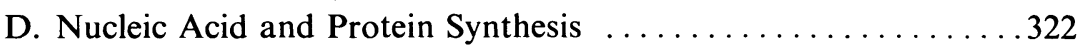

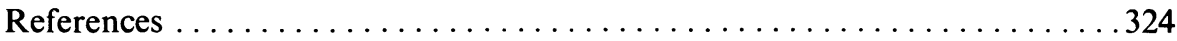

Chapter 9

Biology of the Striatum

André Barbeau

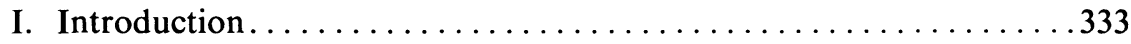

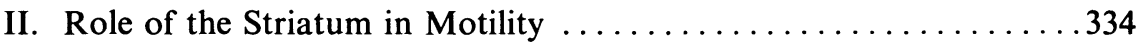

A. "Filter" Mechanism in Tone Control ............... 334

B. "Set" Function of the Striatum ................. 336

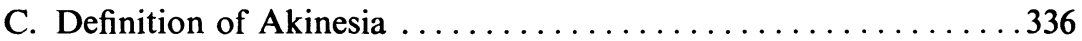

D. "Trigger" Function of the Striatum ................... 339

E. The "Drive" Mechanism .......................... 340

III. Role of the Striatum in Mental Function ............... 340

IV. Role of the Striatum in Autonomic Functions . . . . . . . . . 343

A. Neuronal Regulation of Dopamine Metabolism . . . . . . . . . 344

B. Hormonal Regulation of Dopamine Metabolism . . . . . . . . . 345

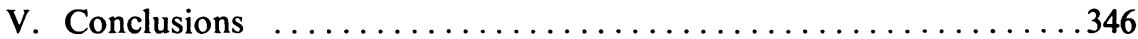

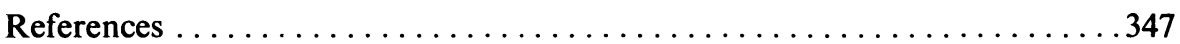

Chapter 10

Pathophysiology of Central Nervous System Regulation of Anterior

Pituitary Function

Dorothy T. Krieger

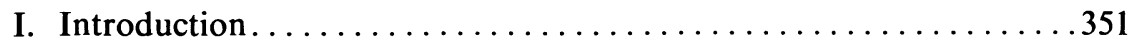

A. Experimental Approaches Utilized $\ldots \ldots \ldots \ldots \ldots \ldots \ldots \ldots \ldots \ldots \ldots \ldots \ldots \ldots$

B. Principles of Neuroendocrine Regulation $\ldots \ldots \ldots \ldots \ldots \ldots 3$ 
II. Concept of Endocrine Regulation Via Releasing Hormones of

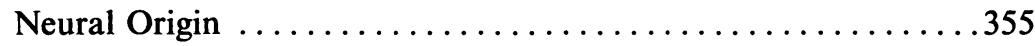

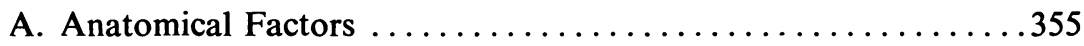

B. Chemical Nature of Hypothalamic Releasing Hormones ......365

C. Mode of Secretion of Hypothalamic Releasing Hormones . . . . 370

D. Mode of Action of Hypothalamic Releasing Hormones .......371

E. Neurotransmitters Involved in the Release of

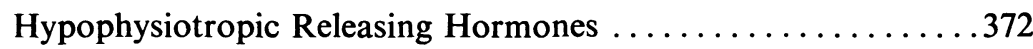

F. Feedback Regulation of Pituitary Hormone Secretion .......375

III. Factors Involved in the Periodic Release of Pituitary

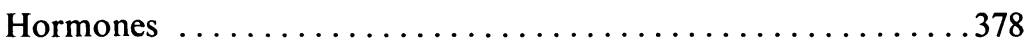

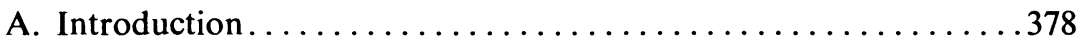

B. Specific Examples of Periodic Hormone Release.... . . . . . . . 379

IV. Effect of Neonatal Hormonal Milieu on Neuroendocrine

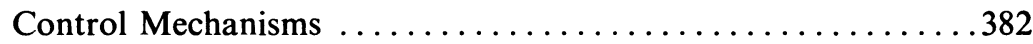

A. Concept of a Critical Period ..................... 382

B. Gonadal Steroids . . . . . . . . . . . . . . . . . . . . 382

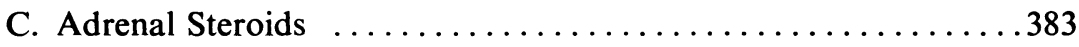

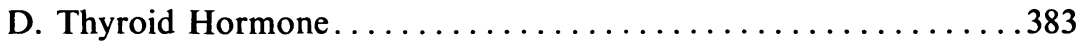

V. Clinical Correlates ............................ 384

A. Testing for Neuroendocrine (Hypothalamic) Dysfunction . . . . 384

B. Endocrine Disorders in CNS Disease ............... 388

C. Clinical Use of Releasing Hormones . . . . . . . . . . . 397

References .........................................

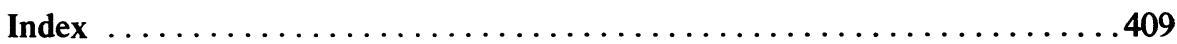

Contents of Volume $1 \ldots \ldots \ldots \ldots \ldots \ldots \ldots \ldots \ldots \ldots \ldots \ldots \ldots \ldots$

Articles Planned for Future Volumes . . . . . . . . . . . . . . . . . . . . . 419 